\author{
Original Article
}

\title{
Effect of different protein based feed on the growth of mahseer
}

\author{
Efeito de alimentação baseada em proteínas diferentes no crescimento de mahseer
}

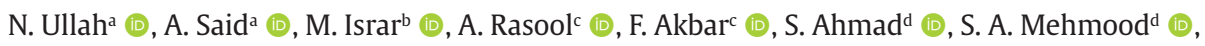

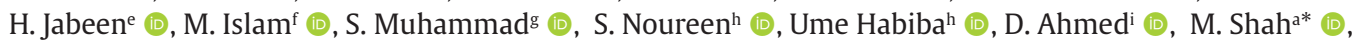 \\ M. A. A. Khan j (D) and M. Sirajk (D)
}

a University of Swat, Centre for Animal Sciences and Fisheries, Charbagh, Pakistan

${ }^{\mathrm{b}}$ University of Swat, Department of Forensics Sciences, Charbagh, Pakistan

' University of Swat, Centre for Biotechnology and Microbiology, Charbagh, Pakistan

${ }^{\mathrm{d}}$ Hazara University Mansehra, Department of Zoology, Mansehra, Pakistan

e Women University Mardan, Department of Microbiology, Mardan, Pakistan

${ }^{\mathrm{f}}$ Hazara University Mansehra, Department of Genetics, Mansehra, Pakistan

${ }^{\mathrm{g}}$ University of Swat, Institute of Agricultural Sciences \& Forestry, Charbagh, Pakistan

${ }^{\mathrm{h}}$ University of Haripur, Department of Forestry and Wildlife Management, Haripur, Pakistan

${ }^{\mathrm{i}}$ University of Haripur, Department of Medical Lab Technology, Haripur, Pakistan

${ }^{\mathrm{j}}$ University of Peshawar: Peshawar, Centre of Biotechnology and Microbiology, Pakistan

${ }^{\mathrm{k}}$ Department of Zoology, Abbottabad University of Science E' Technology, Pakistan

\begin{abstract}
For the proper growth of fish, it is necessary to feed the fish with a proper and balanced diet. A study was conducted to find out the effect of different protein-based diets on fingerlings of Tor putitora (mahseer). A feed with dietary protein levels of $35 \%, 40 \%, 45 \%$, and $50 \%$ were prepared. The effect of different protein-based feed on weight gain, standard growth rate (SGR), food conversion ratio (FCR), percent weight gain, food conversion efficiency (FCE), and protein efficiency ratio (PER) was studied. An increase was observed in the growth rate with an increase in protein concentration up to $45 \%$. The fingerlings fed a $45 \%$ protein diet shown the highest growth, followed by $50 \%, 40 \%$, and $35 \%$. The SGR value was greatest for $45 \%$ protein diet (8.56) followed by $50 \%$ and $40 \%$, while the least values were observed for $35 \%$ protein feed (1.57). The same trend was observed for FCE. The highest PER values was observed in fishes fed $45 \%$ protein-based feed (0.65) followed by $50 \%(0.56), 40 \%(0.38)$ and $35 \%(0.17)$. The food conversion ratio was lowest for $45 \%$ protein diet (3.41), while the greatest for $35 \%$ protein feed (16.85). It was concluded that a $45 \%$ protein-based diet was the best feed formulation for higher production of Tor putitora. However, research on the same percentage of protein diet is recommended for yearlings.
\end{abstract}

Keywords: Tor putitora, protein concentration, weight gain, standard growth rate, food conversion ratio, food conversion efficiency, protein efficiency ratio.

\begin{abstract}
Resumo
Para o bom crescimento dos peixes, é necessário alimentá-los com uma alimentação adequada e balanceada. Um estudo foi realizado para descobrir o efeito de diferentes dietas à base de proteínas em alevinos de Tor putitora (mahseer). Foi preparado um alimento com níveis de proteína dietética de 35\%, 40\%, 45\% e $50 \%$. O efeito de diferentes alimentos à base de proteína no ganho de peso, taxa de crescimento padrão (SGR), taxa de conversão alimentar (FCR), ganho de peso percentual, eficiência de conversão alimentar (FCE) e taxa de eficiência proteica (PER) foi estudado. Foi observado um aumento na taxa de crescimento com um aumento na concentração de proteína de até $45 \%$. Os alevinos alimentados com dieta de $45 \%$ de proteína apresentaram o maior crescimento, seguidos de $50 \%, 40 \%$ e $35 \%$. O valor de SGR foi maior para dieta com $45 \%$ de proteína $(8,56)$, seguido de $50 \%$ e $40 \%$, enquanto os menores valores foram observados para ração com $35 \%$ de proteína $(1,57)$. A mesma tendência foi observada para FCE. Os maiores valores de PER foram observados em peixes alimentados com $45 \%$ de ração à base de proteína $(0,65)$, seguido por $50 \%(0,56), 40 \%(0,38)$ e $35 \%(0,17)$. A taxa de conversão alimentar foi menor para a dieta com $45 \%$ de proteína $(3,41)$, enquanto a maior para a dieta com $35 \%$ de proteína $(16,85)$. Concluiu-se que a dieta à base de proteína de $45 \%$ foi a melhor formulação alimentar para maior produção de Tor putitora. No entanto, a pesquisa sobre a mesma porcentagem de dieta proteica é recomendada para animais de um ano.
\end{abstract}

Palavras-chave: Tor putitora, concentração de proteína, ganho de peso, taxa de crescimento padrão, taxa de conversão de alimentos, eficiência de conversão de alimentos, taxa de eficiência de proteínas.

*e-mail: muzafar@uswat.edu.pk

Received: September 17, 2020 - Accepted: October 21, 2020

This is an Open Access article distributed under the terms of the Creative Commons Attribution License, which permits unrestricted use, distribution, and reproduction in any medium, provided the original work is properly cited. 


\section{Introduction}

Fish culture is the controlled cultivation and harvest of the fish for market sale. There are many methods used, such as cage culture, culturing of the fish in ponds or tanks, etc. The pond is a water reviser that retains water for fish growing purposes and allows their breeding, feeding, and controlled growth, etc. in a well-planned way (Soccol and Oetterer, 2003). Pond culture is economically more viable than cage culture. The recent cage culture was started in the 1950s, using the synthetic materials advent for construction and was practiced in marine water, brackish as well as in freshwater. Fish culture may be monoculture it might be polyculture, depending on the species combinations (Lone and Lone, 2014a).

For proper growth in culturing practice, it is necessary to feed the fish on proper and balanced diets. In intensive culture, the fish depend on artificial feed. To improve fish production, different factors are taken into consideration in artificial feed formulations, such as the feed must be well balanced, complete, and adequate, while the composition, feeding rate, frequency of feeding, consumption, utilization, and feed preparation method are evaluated keenly, and the best possible feed is prepared (Islam et al., 2002). The main ingredients used in supplementary feed are fishmeal, soybean, blood, sunflower, mustard oil cake, soybean cake, groundnut oil cake (GNOC), and soya oil as a protein source, wheat bran, gluten, and rice polish is added as the sources of carbohydrate, and Dicalcium Phosphate (DCP) as $\mathrm{Ca}^{+2}$ and $\mathrm{PO}_{4}^{+2}$ source. Wheat flour, casein, vitamin, mineral premix, and common salt are also used whereas molasses, mineral mixture, Carboxymethylcellulose (CMC), and tapioca are used as binders (Islam et al., 2002; Ullah, 2015). Based on species demand, the concentration of the aforementioned nutrients can be changed in the diets, such as the level of carbohydrates, lipids, and proteins.

The concentration of protein has a direct effect on the growth, physiological, and biochemical aspects of the fish. Mostly feed having higher protein percentage resulted in increased fish growth, weight gain, and specific growth rate (SGR) while a reduced FCR value. Research studies revealed that the increment of protein percentage from $20-45 \%$ in fish feed showed the best standard growth rate, highest protein efficiency ratio (PER), highest values for growth and feed efficiency in different fish species (Lone and Lone, 2013). Lone and Lone (2014b) observed that $45 \%$ protein-based feed was more effective and feasible for fish as compared to a $20 \%$ protein-based diet. Diyaware et al. (2009) investigated the growth performance of hybrid catfish Heterobranchus bidorsalis using different concentrated protein-based diets (35\%, 40\%, $45 \%, 50 \%$, and $55 \%$ ). Their results showed that the fish fed a higher protein-based diet were having a higher growth rate. They observed a linear increase with the increase protein levels up to $50 \%$ in terms of different parameters including mean weight gain (MWG), mean daily weight gain (MDWG), the apparent protein efficiency ratio (APER), protein index (PI), food conversion ratio (FCR), specific growth rate (SGR), nitrogen metabolism (NM), relative growth rate (RGR), and percentage survival (\%SR).

The present study was conducted on mahseer (Tor putitora, Hamilton). It is a very tasty and widely consumed fish species, found around South Asian countries, and is the national fish of Pakistan. Unfortunately, due to habitat loss and other deteriorating environmental factors, its population got declined in most of their indigenous abode, rapidly declining in some parts, whereas it has been declared as a threatened species and got extinct in some parts of Pakistan. Therefore, most of the research studies on mahseer conservation suggested its culture on a wide scale and recommendations have been put forth to prepare the best possible feed, and avoid environmental stressors in order to let it thrive in the wild again (Sawhney and Gandotra, 2009; Ullah et al., 2014, 2015). The study was aimed, to observe the effects of different protein-based artificial diets on the growth of mahseer.

\section{Material and Method}

\subsection{Study site}

The present research was carried out in the Government Mahseer Research Station at Thana, district Malakand, Khyber Pakhtunkhwa, Pakistan. A raceway was divided into four quadrates by putting in silver nets. The coordinates of the study site is $34.645253,72.048378$.

\subsection{Feed formulation}

Feed having four different levels of proteins were prepared in pellet form having 35\%, 40\%, 45\%, and 50\% protein concentrations using fish meal (having 62\% protein), soybean (having $46 \%$ protein), sunflower (having $34 \%$ protein), and canola (having $36 \%$ protein) as protein sources (Ahmad et al., 2004). Rice polish, wheat bran, and gluten were added as sources of carbohydrate. Dicalcium Phosphate (DCP) was used for ions, canola oil as a fats source, and vitamin-premix was added as a source of essential vitamins (Siddiqui and Khan, 2009). All these ingredients were added in a different amount to each feed to obtain the desired concentration of protein (Table 1).

All these ingredients (except oil which was added later) were taken in a specific amount (Table 1 ), properly mixed

Table 1. Amount of ingredients in grams used in different formulated feed for mahseer.

\begin{tabular}{ccccc}
\hline Ingredients & $\mathbf{a} \mathbf{3 5 \%}$ & $\mathbf{b} \mathbf{4 0 \%}$ & $\mathbf{c 4 5 \%}$ & d50\% \\
\hline Fish meal & 20 & 22 & 25 & 25 \\
Soybean meal & 20 & 22 & 25 & 30 \\
Sunflower meal & 20 & 24 & 25 & 29 \\
Canola meal & 18 & 22 & 25 & 30 \\
Rice polish & 20 & 18.3 & 17 & 15 \\
Wheat bran & 20 & 18.3 & 17 & 15 \\
Gluten & 20 & 18.3 & 16 & 15 \\
DCP & 1 & 1 & 1 & 1 \\
Vitamin-Premix & 2 & 2 & 2 & 2 \\
Canola oil & 1 & 1 & 1 & 1 \\
\hline
\end{tabular}

${ }^{a}$ feed contain $35 \%$ protein; ${ }^{b}$ feed contain $40 \%$ protein; ${ }^{\text {cffeed contain } 45 \%}$ protein; dfeed contain $50 \%$ protein. 
grind with the help of an electric blender, and sieved. The oil was added to feed in the given amount. After that, water was added until a dough structure was formed as suggested by Giri et al. (2003). After extruding, long threads of feed were formed and kept under the slow turning fan in a dry place for about 12 hours to dry. The dried feed was ground and the desired size pellets were formed as suggested by Hafedh (1999).

\subsection{Fish sampling}

A total of 24 specimens were stocked to each quadrat after doing their initial morphometry. Initially, body weight and some basic morphometric characters such as total length (TL), fork length (FL), standard length (SL), head length (HL), eye diameter (ED), snout length $(\mathrm{SnL})$, post-orbital length (POL), length of caudal peduncle (LoCP) and body depth (BD) were measured (Table 2). The fish were fed twice a day (morning at 9:00 and dusk at 16:00) in each quadrat at the rate of $4.5 \%$ of their body weight.

\subsection{Measurement of growth parameters}

Month-wise, 8 specimens were captured randomly from each quadrat and were weighed and their morphometric characters were measured. Based on obtained data, other growth parameters such as specific growth rate (SGR), food conversion ratio (FCR), percentage weight (\%WT), food conversion efficiency (FCE), and protein efficiency ratio (PER) were calculated by using following formulae (Sawhney and Gandotra, 2009) (Equations 1-5).

$$
\begin{aligned}
& \mathrm{SGR}=\left(\mathrm{W}_{\mathrm{f}}-\mathrm{W}_{\mathrm{i}} / \text { No. of experimental days }\right) \times 100 \\
& \mathrm{FCR}=\text { Food fed } / \text { Weight gain } \\
& \% \mathrm{WT}=\left(\mathrm{W}_{\mathrm{f}}-\mathrm{W}_{\mathrm{i}} / \mathrm{W}_{\mathrm{i}}\right) \times 100
\end{aligned}
$$

$\mathrm{FCE}=($ Weight gain $/$ Food fed $) \times 100 \mathrm{OR} 1 / \mathrm{FCR} \times 100(4)$
$\mathrm{PER}=$ Weight gain $/$ Protein intake

\section{Result}

The present study was conducted during March through June 2017. The weight of the fish was measured on monthly basis. The initial average weight of all the fish was $8.54 \mathrm{~g}$. The total weight of fish fed $35 \%$ protein feed was $01.46 \mathrm{~g}$ (17.09\%) followed by the group, fed $40 \%$ protein feed (3.96 g, 46.37\%). Fishes fed $45 \%$ protein gained $7.96 \mathrm{~g}$ (93.21\%) weight during the study while fishes fed $50 \%$ protein gained $7.56 \mathrm{~g}(88.52 \%)$ (Table 3$)$.

The total length of the fish was measured four times. The initial average total length was $9.12 \mathrm{~cm}$. Changes in length were observed after one month in fish fed different protein-based feed. Fishes fed by $35 \%$ protein feed gained a total of $01.58 \mathrm{~cm}(17.32 \%)$ followed by fishes fed $40 \%$ protein-based feed $(3.38 \mathrm{~cm}$, $37.06 \%$ ). Fishes fed $45 \%$ protein feed was $12.6 \mathrm{~cm}$ in final measurement, total length increase was $7.38 \mathrm{~cm}$ (80.92\%). Fishes fed by $50 \%$ protein feed had $12.4 \mathrm{~cm}$ final total length, total increase length was $6.98 \mathrm{~cm}$ (76.54\%) (Table 4).

\subsection{Growth parameters measurements}

The gain growth was in the order of $45 \%>50 \%>40 \%>$ $35 \%$ protein-based diet. The average net weight gained was: $7.96 \mathrm{~g}, 7.56 \mathrm{~g}, 3.96 \mathrm{~g}$, and $1.46 \mathrm{~g}$ at $45 \%, 50 \%, 40 \%$, and $35 \%$ protein-based feed respectively. There were a linear increase and direct association between the weight and concentration of protein in the feed. The SGR value highest in fishes fed $45 \%$ protein feed and lowest in those fishes fed 35\% protein feed. The FCR value in this study was highest in the group of fingerlings fed on

Table 2. Different initial morphometric characters (in $\mathrm{cm}$ ) of three fish specimens.

\begin{tabular}{cccccccccc}
\hline Specimens & TL & FL & SL & HL & ED & SnL & POL & LoCP & BD \\
\hline 1. & 10.70 & 9.45 & 8.60 & 2.40 & 0.70 & 0.8 & 1.10 & 1.60 & 2.10 \\
2. & 9.70 & 8.55 & 7.80 & 2.30 & 0.55 & 0.65 & 1.05 & 1.25 & 1.80 \\
3. & 7.10 & 6.20 & 5.70 & 2.05 & 0.40 & 0.60 & 1.00 & 1.00 & 1.50 \\
\hline
\end{tabular}

TL (Total length), FL (Fork length), SL (Standard length), HL (Head length), ED (Eye diameter), SnL (Snout length), POL (Post-orbital length),

\begin{tabular}{|c|c|c|c|c|c|c|}
\hline \multirow[b]{2}{*}{ Feed } & \multicolumn{6}{|c|}{ Weight in grams } \\
\hline & Initial (March) & April & May & June & $\begin{array}{c}\text { Total weight } \\
\text { gained }\end{array}$ & $\begin{array}{c}\text { Percentage of } \\
\text { total weight } \\
\text { gain }\end{array}$ \\
\hline a35\% & 8.54 & 9.17 & 9.6 & 10 & 1.46 & 17.09 \\
\hline b40\% & 8.54 & 10.08 & 11.23 & 12.5 & 3.96 & 46.37 \\
\hline ' $45 \%$ & 8.54 & 11.58 & 13.9 & 16.5 & 7.96 & 93.21 \\
\hline d50\% & 8.54 & 11.51 & 13.7 & 16.1 & 7.56 & 88.52 \\
\hline
\end{tabular}
LoCP (Length of caudal peduncle), and BD (Body depth).

Table 3. Weight of sampled fishes in grams fed by different feeds.

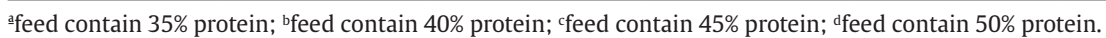


Table 4. Overall measurement of total length (cm).

\begin{tabular}{ccccccc}
\hline & \multicolumn{5}{c}{ Length in cm } \\
\cline { 2 - 6 } Feed & Initial (march) & April & May & June & $\begin{array}{c}\text { Total } \\
\text { Increment in } \\
\text { length }\end{array}$ & $\begin{array}{c}\text { Percent length } \\
\text { increment }\end{array}$ \\
\hline a35\% & 9.12 & 9.7 & 10.2 & 10.7 & 1.58 & $17.32 \%$ \\
b40\% & 9.12 & 10.7 & 11 & 11.55 & 3.38 & 37.06 \\
c45\% & 9.12 & 11.01 & 12.05 & 12.6 & 7.38 & 80.92 \\
d50\% & 9.12 & 11 & 12.03 & 12.5 & 6.98 & 76.54 \\
\hline
\end{tabular}

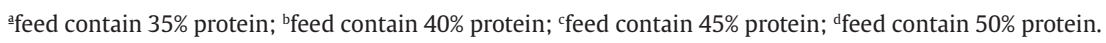

Table 5. Different growth parameters of stocked fingerlings.

\begin{tabular}{|c|c|c|c|c|c|}
\hline S. No & $\begin{array}{c}\text { Growth } \\
\text { parameters }\end{array}$ & a35\% & b40\% & c45\% & d50\% \\
\hline 1. & Weight gained $(\mathrm{g})$ & 1.46 & 3.96 & 7.96 & 7.56 \\
\hline 2. & FCR & 16.85 & 6.53 & 3.41 & 3.59 \\
\hline 3. & FCE & 5.94 & 15.31 & 29.33 & 27.85 \\
\hline 4. & SGR & 1.569 & 4.258 & 8.559 & 8.129 \\
\hline 5. & \%weight gained & 17.09 & 46.37 & 93.21 & 88.52 \\
\hline 6. & PER & 0.17 & 0.38 & 0.65 & 0.56 \\
\hline
\end{tabular}

${ }^{a}$ feed contain $35 \%$ protein; ${ }^{b}$ feed contain $40 \%$ protein; cfeed contain $45 \%$ protein; dfeed contain $50 \%$ protein.

$35 \%$ protein feed (16.85) and lowest for $45 \%$ protein diet fed fish (3.41). In our result, the ratio of FCR decreased with an increase in the concentration of protein up to $45 \%$. The percentage of weight gain in this investigation was highest for the group of fingerlings fed $45 \%$ protein feed while the lowest was for $35 \%$ protein fed fishes. The order of weight gain was $45 \%>50 \%>40 \%>35 \%$ based on the protein diet. Food conversion efficiency (FCE) was observed to be the highest for the fishes fed $45 \%$ protein feed (29.33) and lowest in those fed 35\% protein feed (5.94). The order of FCE was $45 \%>50 \%>40 \%>35 \%$ protein-based diet. The protein efficiency ratio (PER) was the lowest for $35 \%$ protein feed while the highest for $45 \%$ protein-based feed. The values of PER were 0.17, 0.38, 0.65, and 0.56 for fish fed $35 \%, 40 \%, 45 \%$, and $50 \%$ protein-based feed formulations respectively (Table 5 ).

\section{Discussion}

Mahseer (Tor putitora) fingerlings fed on different proteinbased feed contain various protein concentrations (35\%, $40 \%, 45 \%$, and $50 \%$ ) for 3 months. The findings of the result expressed that the fingerlings fed $45 \%$ protein-based feed attained the highest weight, while those fed $35 \%$ protein feed attained the lowest weight. The order of weight gain in fishes fed different protein-based feed was $45 \%>50 \%>$ $40 \%>35 \%$. The average net weight gained was $7.96 \mathrm{~g}, 7.56 \mathrm{~g}$, $3.96 \mathrm{~g}$, and 1.46 for $45 \%, 50 \%, 40 \%$, and $35 \%$ protein-based feed respectively. The results of the current study shown similarities with the results of Akand et al. (1989) as they observed that the weight gain of the fish increased with increasing levels of dietary protein from $19.87 \%$ to $35.43 \%$. A similar result was also shown by Diyaware et al. (2009).

Similarly, Ahmad et al. (2004) conducted research and observed the highest growth, final weight gain, percent weight gain, and SGR for Nile tilapia fry fed a $45 \%$ protein diet followed by those fed $35 \%$, and the poorest growth performance of fish fry was obtained for the fish fed 25\% protein diet. According to Siddiqui and Khan (2009), the SGR for fries of on fry and young Nile Tilapia fed on feed containing $20 \%$ of the protein was the lowest (0.989) and was the highest (1.276) for fish fed a $40 \%$ protein-based diet. In our investigation, the SGR value was highest for fingerling fed $45 \%$ proteinbased feed, and the lowest for 35\% protein fed to fish. So all the studies show similarities. The present study indicates that the FCR value was greatest in the group of fingerlings fed 35\% protein-based feed (16.85) and lowest in those fed $45 \%$ protein feed (3.41). Low FCR in a $45 \%$ protein diet showed its efficient utilization. According to Siddiqui and Khan (2009), the FCR of fishes fed $20 \%$ protein was the highest (2.397), whereas they observed $1.964,1.894$, and 2.324 for $30 \%, 40 \%$, and for $50 \%$ protein-based fed fish groups. Both the research shows similarities. A similar result was also indicated by Lone and Lone, $\left(2014^{\mathrm{a}}\right)$.

In our investigation Protein efficiency ratio (PER) was the lowest $(0.17)$ in those fed $35 \%$ protein feed while the greatest $(0.65)$ in those fed a $45 \%$ protein diet. The result indicates the increment in protein concentration 
in feed leads to a high value of PER. the According to Sarkar et al. (2015), Protein efficiency ratio (PER) is directly proportional to the percentage of protein they observed that the group fed $15 \%$ of protein their PER was the lowest $(0.07 \pm 0.01)$ while those fed $25 \%$ protein was having the highest PER $(2.04 \pm 0.02)$. A similar result was also shown by Lone and Lone (2014a). Hafedh (1999) conducted a study on Nile Tilapia to find out the effect of various dietary proteins $(25 \%, 30 \%, 35 \%, 40 \%$, and $45 \%)$ on their growth performance. They reported the best PER value $(1.69 \pm 0.2)$ in fishes fed $30 \%$ protein while the lowest ( $1.39 \pm 0.1$ ) value was observed for the fish fed $45 \%$ protein. The differences of these studies and variation as compared to the present study might be due to the use of different species, as well as changes in climatic condition and water quality of the study area and ambient water respectively. Food conversion efficiency (FCE) was observed to be the highest for the fingerlings fed a $45 \%$ protein diet (29.33) while the lowest in those fed 35\% protein feed (5.94). According to Sawhney and Gandotra (2009), among 30\%, 35\%, 40\%, 45\% 50\% protein-based feeds, the FCE in fish fed $30 \%$ protein diet was the lowest (7.621) while that fed on $45 \%$ was having the highest FCE (14.46). According to Akand et al. (1989), the FCE value for $0 \%$ protein was $0.44 \pm 0.02$, while the highest FCE $(0.56 \pm 0.02)$ was observed for the fish fed the highest protein level (39.1).

\section{Conclusion}

The study concluded that the most effective feed for the fingerlings of Tor putitora was a $45 \%$ protein-based diet. Fish fed $45 \%$ protein-based diet attained the best growth, in terms of increase in body weight and body length, and also led to effects on the growth parameters (SGR, FCR, PER, and FCE). For better culture and higher production of mahseer at Mahseer Research center Thana (Malakand district, Khyber Pakhtunkhwa) and mahseer farmers at the adjoining/adjacent areas, a $45 \%$ protein-based diet is recommended.

\section{References}

AHMAD, M.H., ABDEL TAWWAB, M. and KHATTAB, Y.A., 2004. Effect of dietary protein levels on growth performance and protein utilization in Nile tilapia (Oreochromis niloticus L.) with different initial body weights. In: 6th International Symposium on Tilapia in Aquaculture Proceedings, 2004, Manila, Philippines. Cabanatuan City: Creative Unlimited, pp. 249-263.

AKAND, A., MIAH, M. and HAQUE, M., 1989. Effect of dietary protein level on growth, feed conversion and body composition of shingi (Heteropneustes fossilis Bloch). Aquaculture, vol. 77, no. 2-3, pp. 175-180. http://dx.doi.org/10.1016/0044-8486(89)90200-7.

DIYAWARE, M.B., MODU, B.N. and YAKUBU, U.P., 2009. Effect of different dietary protein levels on growth performance and feed utilization of hybrid catfish (Heterobranchus bidorsalis $\times$
Clarias anguillaris) fry in north-east Nigeria. African Journal of Biotechnology, vol. 8, no. 16, pp. 111-123.

GIRI, S.S., SAHOO, S.K., SAHU, A.K. and MEHER, P.K., 2003. Effect of dietary protein level on growth, survival, feed utilisation and body composition of hybrid clarias catfish (Clarias batrachus $\mathrm{x}$ Clarias gariepinus). Animal Feed Science and Technology, vol. 104, no. 1-4, pp. 169-178. http://dx.doi.org/10.1016/S03778401(02)00295-X.

HAFEDH, A.Y., 1999. Effects of dietary protein on growth and body composition of Nile tilapia, Oreochromis niloticus. Aquaculture Research, vol. 30, no. 5, pp. 385-393. http://dx.doi.org/10.1046/ j.1365-2109.1999.00343.x.

ISLAM, M.S., HUSSAIN, D.M., HOSSAIN, M. and MAZID, M., 2002. Feed utilization and wastage in semi-intensive pond culture of mahseer, Tor putitora (Ham.). Bangladesh Journal of Fisheries Research, vol. 6, pp. 1-9.

LONE, A. and LONE, S., 2013. Dietary protein inclusion to assess growth and feed utilization in Tor tor (Hamilton, 1822). Walailak Journal of Science and Technology, vol. 11, pp. 33-40.

LONE, A. and LONE, S., 2014a. Biochemical changes in proximate and body composition of Tor tor (Hamilton, 1822) fed with various concentrations of protein. e-Journal of Science \& Technology, vol. 2, no. 9, pp. 59-64.

LONE, A. and LONE, S., 2014b. Effects of dietary protein levels on growth, feed utilization, protein retention efficiency of Tor tor (Hamilton, 1822). Journal of Aquaculture Feed Science and Nutrition, vol. 6, pp. 1-5.

SARKAR, S., MOHANTY, S.N., NAYAK, K.C., PRADHAN, C., MOHANTA, K.N. and DEVARAJ, C., 2015. Protein requirement of ir-jayanti (Labeo rohita) fingerlings. International Journal of Fisheries and Aquatic Studies, vol. 3, pp. 324-330.

SAWHNEY, S. and GANDOTRA, R., 2009. Growth response and feed conversion efficiency of Tor putitora (Ham.) fry at varying dietary protein levels. Pakistan Journal of Nutrition, vol. 9, no. 1, pp. 86-90. http://dx.doi.org/10.3923/pjn.2010.86.90.

SIDDIQUI, T.Q. and KHAN, M.A., 2009. Effects of dietary protein levels on growth, feed utilization, protein retention efficiency and body composition of young Heteropneustes fossilis (Bloch). Fish Physiology and Biochemistry, vol. 35, no. 3, pp. 479-488. http://dx.doi.org/10.1007/s10695-008-9273-7. PMid:18998230.

SOCCOL, M.C.H. and OETTERER, M., 2003. Seafood as functional food. Brazilian Archives of Biology and Technology, vol. 46, no. 3, pp. 443-454. http://dx.doi.org/10.1590/S151689132003000300016.

ULLAH, R., ZUBERI, A., NAEEM, M. and ULLAH, S., 2015. Toxicity to hematology and morphology of liver, brain and gills during acute exposure of Mahseer (Tor putitora) to cypermethrin. International Journal of Agriculture and Biology, vol. 17, pp. 199-204.

ULLAH, R., ZUBERI, A., ULLAH, S., ULLAH, I. and ULLAH DAWAR, F., 2014. Cypermethrin induced behavioral and biochemical changes in mahseer, Tor putitora. The Journal of Toxicological Sciences, vol. 39, no. 6, pp. 829-836. http://dx.doi.org/10.2131/ jts.39.829. PMid:25374374

ULLAH, S., 2015. Protective role of vitamin C against Cypermethrin induced toxicity in Labeo rohita (Ham.): biochemical aspects. Islamabad, Pakistan: Department of Animal Sciences. Quaidi-Azam University, 66 p. M.Phil. Thesis. 